\title{
Clostridium nitrophenolicum sp. nov., a novel anaerobic $p$-nitrophenol-degrading bacterium, isolated from a subsurface soil sample
}

Correspondence

R. K. Jain

rkj@imtech.res.in

\author{
K. Suresh, D. Prakash, N. Rastogi and R. K. Jain
}

Microbial Type Culture Collection and Gene bank (MTCC), Institute of Microbial Technology, Sector 39A, Chandigarh - 160 036, India
The genus Clostridium is one of the largest genera among prokaryotes that constitute anaerobic, Gram-positive and endospore-forming bacteria. They have been isolated from soil, sediment, decomposing biological material and the lower gut of mammals. Members of the genus Clostridium have diverse metabolic capabilities and are known to possess strong nitroreductase properties that have been extensively investigated with purified enzymes and cell cultures (Spain et al., 2000). Attempts have been made to exploit this property for the remediation of soil contaminated with polynitroaromatics such as 2,4-dinitrophenol, 2,4,6-trinitrotoluene, 1,3,5-trinitrohexahydro-1,3,5-triazine etc. (Gorontzy et al., 1993; Hughes et al., 1998, 1999; Lewis et al., 1996; Shin et al., 1997). However, little is known about the Clostridium species that degrade mononitrophenols such as $p$-nitrophenol (pNP) and $m$-nitrophenol. To our knowledge, there is only a single report available on pNP

Abbreviations: DPG, diphosphatidylglycerol; PE, phosphatidylethanolamine; PG, phosphatidylglycerol; pNP, p-nitrophenol.

The GenBank/EMBL/DDBJ accession number for the 16S rRNA gene sequence of strain $1 D^{\top}$ is $A M 261414$.

A table detailing the cellular fatty acid composition of strain $1 D^{\top}$ and Clostridium aciditolerans is available with the online version of this paper. transformation by Clostridium pasteurianum and Clostridium sp. W1 under anaerobic conditions (Gorontzy et al., 1993). In the present study, by using the polyphasic approach, we determined the taxonomic position of the bacterial strain $1 \mathrm{D}^{\mathrm{T}}$ that is capable of degrading pNP under anaerobic conditions.

The bacterium $1 \mathrm{D}^{\mathrm{T}}$ was isolated from a soil sample (redsandy soil) in a pot that was obtained from the subsurface environment from a depth of about 3-4 $\mathrm{m}$ during an archaeological survey at Hyderabad, India located between longitude $78^{\circ} 30^{\prime}$ east and latitude $17^{\circ} 23^{\prime}$ north. The sample yielding strain $1 \mathrm{D}^{\mathrm{T}}$ was isolated by performing standard plate-dilution technique on tryptone soy agar (TSA; Himedia), with $0.01 \%$ of resazurin as an indicator, at $30{ }^{\circ} \mathrm{C}$ under anaerobic conditions. The isolate was maintained as a glycerol stock at $-70{ }^{\circ} \mathrm{C}$ until further characterization. The reference strain Clostridium aciditolerans DSM $17425^{\mathrm{T}}$ was obtained from DSMZ, Germany.

Strain $1 \mathrm{D}^{\mathrm{T}}$ was found to be an obligate anaerobe and it formed a cream coloured colony. Cell morphology was observed under a phase-contrast microscope (Zeiss, Axiophot) using an oil-immersion objective $(\times 100)$ to ascertain the shape. Presence of spore formation was 
determined by staining with malachite green as described previously (Gerhardt et al., 1994). Motility was confirmed by using the hanging-drop method immediately after taking out the culture from anaerobic conditions. Physiological tests such as growth at different temperatures, $\mathrm{pH}$ and salt concentrations were performed using basal TSA medium with L-cysteine hydrochloride $(0.05 \%)$ as a reducing agent. Strain $1 \mathrm{D}^{\mathrm{T}}$ was found to grow between temperatures 20 and $45{ }^{\circ} \mathrm{C}$ with optimum growth at $30{ }^{\circ} \mathrm{C}$. Biological buffers (pH 5.5-6.5 MES and 7.5-8.5 $\mathrm{NaHCO}_{3} /$ $\mathrm{Na}_{2} \mathrm{CO}_{3}$ system) were used for $\mathrm{pH}$ adjustment. The efficiency of strain $1 \mathrm{D}^{\mathrm{T}}$ to degrade pNP was tested in tryptone soy broth (TSB) supplemented with $0.2-0.5 \mathrm{mM}$ of pNP in serum, vials under anaerobic conditions. Analysis on quantification of pNP was done by using HPLC with a Waters 600 model equipped with a Waters 996 photodiode array detector operating at $315 \mathrm{~nm}$. Separation was carried out with a Waters Spherisorb $5 \mu \mathrm{m}$ C8 column and the mobile phase was $1 \%$ acetic acid/methanol (solvent $\mathrm{A}$ ) and $1 \%$ acetic acid/water (solvent B). Compounds were eluted at a flow rate of $1.5 \mathrm{ml} \mathrm{min}^{-1}$ by using a gradient starting with $35 \%$ of solvent A followed by a gradual increase to $68 \%(0-10 \mathrm{~min})$.
For biochemical tests mentioned in Table 1 and species description, strain $1 \mathrm{D}^{\mathrm{T}}$ was grown at $30{ }^{\circ} \mathrm{C}$ on TSA medium with L-cysteine hydrochloride $(0.05 \%)$ as a reducing agent and under anaerobic conditions. Catalase and oxidase tests were carried out as described by Cowan \& Steel (1965). Indole test, Voges-Proskauer test, methyl red test, $\mathrm{H}_{2} \mathrm{~S}$ production and nitrate reduction were performed as described by Lanyi (1987). Casein, gelatin, starch and Tween 20 hydrolysis were determined as described by Smibert \& Krieg (1994). Assimilation of various substrates by strain $1 \mathrm{D}^{\mathrm{T}}$ was determined by using the Biolog system according to the manufacturer's instructions except that reinforced clostridial agar (RCA, Himedia) was used instead of the Biolog Universal agar with $5 \%$ blood. Furthermore, the ability of strain $1 \mathrm{D}^{\mathrm{T}}$ to produce acid from sugar was

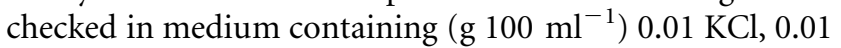
yeast extract, $0.025 \mathrm{~K}_{2} \mathrm{HPO}_{4}, 0.025 \mathrm{MgSO}_{4}, 0.2\left(\mathrm{NH}_{4}\right)_{2} \mathrm{SO}_{4}$, 0.01 bromocresol purple supplemented with $1.0 \%$ of each filter-sterilized carbon compound. Fatty acid methyl esters (Sato \& Murata, 1988) were extracted from cells grown on TSA with L-cysteine hydrochloride $(0.05 \%)$ at $30{ }^{\circ} \mathrm{C}$ under anaerobic conditions and analysed by Microbial Identification System (MIDI) as described by Pandey et

Table 1. Characteristics that differentiate strain $1 D^{\top}$ from related species of the genus Clostridium

Strains: 1, C. nitrophenolicum $1 \mathrm{D}^{\mathrm{T}} ; 2$, C. aciditolerans JW/YJL-B3 ${ }^{\mathrm{T}} ; 3$, C. drakei SL1 ${ }^{\mathrm{T}} ; 4$, C. scatologenes ATCC 25775 ${ }^{\mathrm{T}}$; 5, C. carboxidivorans $\mathrm{P7}^{\mathrm{T}}$; 6, C. magnum ATCC $49199^{\mathrm{T}}$. Data are from this and earlier studies (Lee et al., 2007; Liou et al., 2005; Küsel et al., 2000; Schink, 1984). +, Positive; - , negative; NR, not reported.

\begin{tabular}{|c|c|c|c|c|c|c|}
\hline Characteristic & 1 & 2 & 3 & 4 & 5 & 6 \\
\hline Temperature optimum $\left({ }^{\circ} \mathrm{C}\right)$ & 30 & 35 & $30-37$ & $37-40$ & 38 & $15-45$ \\
\hline Gelatin hydrolysis & + & + & - & NR & - & - \\
\hline Casein hydrolysis & + & - & NR & NR & NR & NR \\
\hline Esterase activity & - & + & NR & NR & NR & NR \\
\hline Cellobiose & - & + & + & + & + & NR \\
\hline Citrate & - & NR & NR & NR & NR & + \\
\hline Glucose & - & + & + & + & + & + \\
\hline Lactose & - & + & - & - & - & NR \\
\hline Malate & - & NR & + & NR & - & + \\
\hline Maltose & - & + & - & + & - & NR \\
\hline Ribose & - & + & + & NR & + & NR \\
\hline Sucrose & - & + & + & NR & + & + \\
\hline Xylose & - & + & + & + & + & + \\
\hline $\begin{array}{l}\text { End products of glucose } \\
\text { fermentation }\end{array}$ & $\begin{array}{l}\text { Formate, } \\
\text { acetate and } \\
\text { pyruvate }\end{array}$ & $\begin{array}{c}\text { Acetate, } \\
\text { butyrate and } \\
\text { ethanol }\end{array}$ & $\begin{array}{c}\text { Acetate, butyrate, } \\
\text { ethanol and } \\
\text { butanol }\end{array}$ & $\begin{array}{c}\text { Acetate and } \\
\text { butyrate }^{\star}\end{array}$ & $\begin{array}{c}\text { Acetate, butyrate, } \\
\text { ethanol and } \\
\text { butanol }\end{array}$ & $\begin{array}{l}\text { Acetate } \\
\text { and } \mathrm{CO}_{2}\end{array}$ \\
\hline DNA G $+\mathrm{C}$ content $(\mathrm{mol} \%)$ & 35.5 & 30.8 & 32 & 31 & 31 & 29.1 \\
\hline
\end{tabular}

${ }^{\star}$ End products of fructose fermentation. 
al. (2002). Peptidoglycan type was analysed according to Komagata \& Suzuki (1987) and menaquinones were extracted and analysed as described by Minnikin et al. (1984). Polar lipids were analysed as described by Suresh et al. (2004). Fermentation end products of glucose were determined by GC with a flame-ionization detector (Shimadzu) as described by Mountfort \& Rhodes (1991). DNA was isolated as described by Shivaji et al. (1989). The $\mathrm{G}+\mathrm{C}$ content of genomic DNA was determined as described by Mesbah et al. (1989). The enzymically degraded nucleosides were separated by HPLC using a reverse-phase column (C18; Phenomenex); non-methylated $\lambda$ DNA (49.85 mol\% G $+\mathrm{C}$ ) was used as the calibration reference. DNA-DNA hybridization was performed by the membrane filter method (Tourova \& Antonov, 1987) as described by Shivaji et al. (1992).

Cells in young culture were Gram-positive rods, strictly anaerobic and motile. Other characteristics are described in Table 1 and the species description. They grew well in medium containing $\mathrm{pNP}$ at a concentration of $0.5 \mathrm{mM}$. HPLC analysis revealed that strain $1 \mathrm{D}^{\mathrm{T}}$ is capable of degrading $\mathrm{pNP}$ and the complete degradation of $\mathrm{pNP}$ was observed within $24 \mathrm{~h}$ as there was no pNP spectrum observed through HPLC analysis. Neither intermediate(s) nor end product(s) was observed during the anaerobic degradation of $\mathrm{pNP}$, suggesting complete degradation by strain $1 \mathrm{D}^{\mathrm{T}}$. However, further characterization of the biochemical steps involved in the degradation is the subject of future studies.

The 16S rRNA gene was amplified by PCR using primers 8-27f ( $5^{\prime}$-AGAGTTTGATCCTGGCTCAG-3') and $1492 \mathrm{r}$ (5'-TACGGYTACCTTGTTACGACTT- ${ }^{\prime}$ ) as described by Pandey et al. (2002). Amplified PCR product was purified using QIAquick PCR purification kit (Qiagen), sequenced using the Big Dye Terminator kit (Applied Biosystems) and an ABI Prism model $3130 \times 1$ automatic DNA sequencer. The almost-complete 16S rRNA gene sequence (1461 bp continuous stretch) was obtained and used for the initial BLAST search. Closely related sequences were retrieved from the EMBL database. For alignment, CLUSTAL_X was used (Thompson et al., 1997) and the results obtained were edited manually. Pair-wise evolutionary distances were calculated using the Kimura two-parameter model (Kimura, 1980). A neighbour-joining phylogenetic tree was constructed using TREECON (version 1.3b) (Van de Peer \& De Wachter, 1997). The stability among the groupings of the phylogenetic tree was assessed based on 1000 replicates. Sporacetigenium mesophilum DSM $16796^{\mathrm{T}}$ (AY682207) was used as the outgroup.

Phylogenetic analysis based on the 16S rRNA gene sequence indicated that strain $1 \mathrm{D}^{\mathrm{T}}$ represents a novel species of the genus Clostridium. It exhibited highest similarity to $C$. aciditolerans JW/YJL-B3 ${ }^{\mathrm{T}}$ (98.2\%) followed by Clostridium scatologenes ATCC $25775^{\mathrm{T}}$ (95.1\%), Clostridium drakei $\mathrm{SL}^{\mathrm{T}}$ (95.0\%), Clostridium carboxidivorans $\mathrm{P}^{\mathrm{T}}(95.0 \%)$ and much lower similarity to other species of the genus with validly published names. Although Clostridium magnum ATCC $49199^{\mathrm{T}}$ showed $95.3 \%$ similarity in pairwise sequence analysis, there was complete dissimilarity observed between nt 980 and 1022 (according to Escherichia coli number) that was not taken into account. The neighbour-joining phylogenetic analysis revealed that strain $1 \mathrm{D}^{\mathrm{T}}$ formed a clade with the type strain of $C$. aciditolerans, with $100 \%$ bootstrap value (Fig. 1), and formed a coherent cluster with other members of cluster I of the genus Clostridium (Collins et al., 1994). Strain $1 \mathrm{D}^{\mathrm{T}}$ showed highest similarity to $C$. aciditolerans at $16 \mathrm{~S}$ rRNA gene sequence level; however, it exhibited only $36.4 \%$ mean value of DNA-DNA hybridization at whole genome level, which is significantly below the recommended threshold

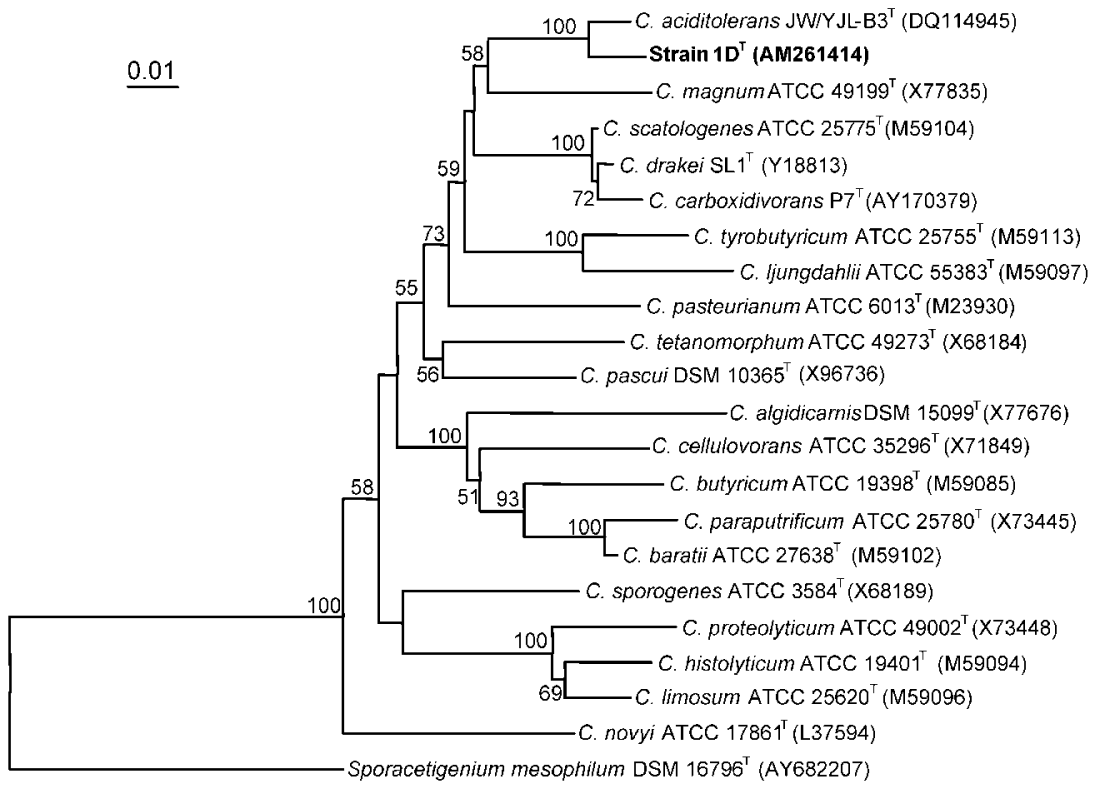

Fig. 1. Neighbour-joining phylogenetic tree based on 16S rRNA gene sequences (1461 bases) showing the relationship between strain $1 \mathrm{D}^{\top}$ and other related species of the genus Clostridium. Bootstrap values greater than $50 \%$ are given at the nodes. Bar, 0.01 substitutions per site. 
value of less than $70 \%$ for the delineation of a new species (Wayne et al., 1987). There were several phenotypic properties as well as end products of glucose fermentation to distinguish strain $1 \mathrm{D}^{\mathrm{T}}$ from C. aciditolerans (Table 1). The fatty acid analysis of strains $1 \mathrm{D}^{\mathrm{T}}$ and C. aciditolerans indicated that they had $\mathrm{C}_{16: 0}$, iso- $\mathrm{C}_{17: 1} \mathrm{I} /$ anteiso $\mathrm{B}$ and $\mathrm{C}_{14: 0}$ as major components; however, fatty acids iso- $\mathrm{C}_{13: 0}$, $\mathrm{C}_{13: 0}$, iso- $\mathrm{C}_{15: 0}$, anteiso- $\mathrm{C}_{15: 0}, \mathrm{C}_{15: 1} \omega 8 c, \mathrm{C}_{15: 1} \omega 6 c$ and iso- $\mathrm{C}_{18: 1} \mathrm{H}$ were present in $C$. aciditolerans in significant quantities but absent in strain $1 \mathrm{D}^{\mathrm{T}}$ (see Supplementary Table S1 available in IJSEM Online). Presence of $\mathrm{C}_{16: 0}$ as a major fatty acid, which is also reported in other species (Wilde et al., 1997; Broda et al., 2000a, b; Spring et al., 2003), further affiliates strain $1 \mathrm{D}^{\mathrm{T}}$ to the genus Clostridium. The polar lipid analysis revealed the presence of diphosphatidylglycerol (DPG), as a major lipid and other lipids include phosphatidylglycerol (PG), phosphatidylethanolamine (PE) and two unknown phospholipids. Based on these data presented, strain $1 \mathrm{D}^{\mathrm{T}}$ represents a novel species in the genus Clostridium, for which the name Clostridium nitrophenolicum sp. nov. is proposed.

\section{Description of Clostridium nitrophenolicum sp. nov.}

Clostridium nitrophenolicum (ni.tro.phen.o'li.cum. N.L. n. nitrophenol; L. suff. -icus - $a$-um suffix used with the sense of belonging to; N.L. neut. adj. nitrophenolicum referring to the substrate nitrophenol that can be utilized by the species).

Cells are rod shaped measuring 3.5-5.0 $\mu \mathrm{m}$ in length and $0.6-0.9 \mu \mathrm{m}$ in width and strictly anaerobic. They form spores that are oval and central in position. Colonies grown on TSA are circular, smooth and convex with wavy margin. Growth occurs between pH 6.5 and 8.0 and no growth is observed below pH 6.5 and above 8.0. Growth occurs between 20 and $45{ }^{\circ} \mathrm{C}$ and does not grow at 15 or $50{ }^{\circ} \mathrm{C}$. Optimum growth is observed at $\mathrm{pH} 7.2$ and temperature $30{ }^{\circ} \mathrm{C}$. Growth occurs between 0 and $1 \% \mathrm{NaCl}$ and does not grow with $2.0 \% \mathrm{NaCl}$. Strain $1 \mathrm{D}^{\mathrm{T}}$ is negative for catalase and oxidase, and positive for indole and methyl red test. Starch and urea are not hydrolysed. Does not reduce nitrate to nitrite and is negative for VogesProskauer test, citrate utilization and $\mathrm{H}_{2} \mathrm{~S}$ production. Using Biolog MicroPlates (AN), the strain showed a positive reaction for the assimilation of $\mathrm{D}$-fructose, L-fucose, D-galactose, D-galacturonic acid, palatinose and L-rhamnose and a negative reaction for acetic acid, $\mathrm{N}$ acetyl-D-galactosamine, $\mathrm{N}$-acetyl-D-glucosamine, $\mathrm{N}$-acetyl$\beta$-D-mannosamine adonitol, L-alaninamide, L-alanine, L-alanyl L-glutamine, L-alanyl L-histidine, L-alanyl Lthreonine, amygdalin, D-arabitol, arbutin, L-asparagine, D-cellobiose, $\alpha$-cyclodextrin, $\beta$-cyclodextrin, dextrin, dulcitol, $i$-erythritol, formic acid, D-gluconic acid, $\alpha$-D-glucose 1-phosphate, $\alpha$-D-glucose 6-phosphate, L-glutamic acid, Lglutamine, glycerol, glyoxylic acid, $\alpha$-hydroxybutyric acid, $\beta$-hydroxybutyric acid, inosine, myo-inositol, itaconic acid, $\alpha$-ketobutyric acid, $\beta$-ketobutyric acid, lactic acid, lactulose, malic acid, maltose, maltotriose, D-mannitol, mannose, D-melibiose, L-methionine, methyl $\beta$-D-galactoside, methyl $\alpha$-D-glucoside, methyl $\beta$-D-glucoside, 3methyl-D-glucose, L-phenylalanine, propionic acid, pyruvic acid, D-raffinose, L-rhamnose, D-saccharic acid, salicin, Lserine, D-sorbitol, stachylose, succinic acid, sucrose, $m$ tartaric acid, L-threonine, thymidine, trehalose, turanose, uridine, urocanic acid and L-valine. It produced acid from glucose, dulicitol, fructose, galactose, maltose, mannose, sucrose and trehalose, but not from adonitol, arabinose, cellobiose, inositol, mannitol, melibiose, salicin or sorbitol. Fermentation end products from glucose include acetate, formate and pyruvate. Menaquinone present is MK-7 and the cell wall amino acid is meso-diaminopimelic acid. Polar lipids present are DPG, PG, PE and two unknown phospholipids (UKP1 and UKP2). The major cellular fatty acids are (\%); $\mathrm{C}_{16: 0}(28.02)$, iso- $\mathrm{C}_{17: 1} \mathrm{I} /$ anteiso $\mathrm{B}$ (23.05), $\mathrm{C}_{16: 1} \omega 7 c /$ iso- $\mathrm{C}_{15: 0} 2-\mathrm{OH}(10.82)$ and $\mathrm{C}_{14: 0}$ (10.02). The DNA G $+\mathrm{C}$ content is $35.5 \mathrm{~mol} \%$.

The type strain, $1 \mathrm{D}^{\mathrm{T}}\left(=\right.$ MTCC $\left.7832^{\mathrm{T}}=\mathrm{JCM} 14030^{\mathrm{T}}\right)$, was isolated from a subsurface soil sample from a depth of about 3-4 m.

\section{Acknowledgements}

This work was supported, in part, by the Council of Scientific and Industrial Research (CSIR) and Department of Biotechnology (DBT). We are thankful to Dr Peter Schumann, DSM, Germany, for guiding us in determining $\mathrm{G}+\mathrm{C}$ content of DNA by the HPLC method, and Ms Anuradha Ghosh and Ms Archana Chauhan for their help and reading the manuscript. This is IMTECH communication number 28/2006.

\section{References}

Broda, D. M., Saul, D. J., Lawson, P. A., Bell, R. G. \& Musgrave, D. R. (2000a). Clostridium gasigenes sp. nov., a psychrophile causing spoilage of vacuum-packed meat. Int J Syst Evol Microbiol 50, 107-118.

Broda, D. M., Saul, D. J., Bell, R. G. \& Musgrave, D. R. (2000b). Clostridium algidixylanolyticum sp. nov., a psychrotolerant, xylandegrading, spore-forming bacterium. Int J Syst Evol Microbiol 50, 623-631.

Collins, M. D., Lawson, P. A., Willems, A., Cardoba, J. J., FernandezGarayzabal, J., Garcia, P., Cai, J., Hippe, H. \& Farrow, J. A. E. (1994). The phylogeny of the genus Clostridium: proposal of five new genera and eleven new species combinations. Int J Syst Bacteriol 44, 812-826.

Cowan, S. T. \& Steel, K. J. (1965). Manual for the Identification of Medical Bacteria. London: Cambridge University Press.

Gerhardt, P., Murray, R. G. E., Wood, W. A. \& Krieg, N. R. (editors) (1994). Methods for General and Molecular Bacteriology. Washington, DC: American Society for Microbiology.

Gorontzy, T., Kuver, J. \& Blotevogel, K. H. (1993). Microbial transformation of nitroaromatic compounds under anaerobic conditions. J Gen Microbiol 139, 1331-1336.

Hughes, J. B., Wang, C. W., Bhadra, R., Richardson, A., Bennett, G. N. \& Rudolph, F. (1998). Reduction of 2,4,6-trinitrotoluene by Clostridium acetobutylicum through hydroxylamino-nitrotoluene intermediates. Environ Toxicol Chem 17, 343-348.

Hughes, J. B., Chuan, Y. W. \& Chunlong, Z. (1999). Anaerobic biotransformation of 2,4-dinitrotoulene and 2,6-dinitrotoulene by 
Clostridium acetobutylicum: a pathway through dihydroxylamino intermediates. Environ Sci Technol 33, 1065-1070.

Kimura, M. (1980). A simple method for estimating evolutionary rates of base substitutions through comparative studies of nucleotide sequences. J Mol Evol 16, 111-120.

Komagata, K. \& Suzuki, K. (1987). Lipid and cell wall analysis in bacterial systematics. Methods Microbiol 19, 161-207.

Küsel, K., Dorsch, T., Acker, G., Stackebrandt, E. \& Drake, H. L. (2000). Clostridium scatologenes strain SL1 isolated as an acetogenic bacterium from acidic sediments. Int J Syst Evol Microbiol 50, 537-546.

Lanyi, B. (1987). Classical and rapid identification methods for medically important bacteria. Methods Microbiol 19, 1-67.

Lee, Y.-J., Romanek, C. S. \& Wiegel, J. (2007). Clostridium aciditolerans sp. nov., an acid tolerant spore-forming anaerobic bacterium from constructed wetland sediment. Int J Syst Evol Microbiol 57, 311-315.

Lewis, T. A., Goszcynski, S., Crawford, R. L., Korus, R. A. \& Admassu, W. (1996). Products of anaerobic 2,4,6-trinitrotoluene (TNT) transformation by Clostridium bifermentans. Appl Environ Microbiol 62, 4669-4674.

Liou, J. S.-C., Balkwill, D. L., Drake, G. R. \& Tanner, R. S. (2005). Clostridium carboxidivorans sp. nov., a solvent-producing Clostridium isolated from an agricultural settling lagoon, and reclassification of the acetogen Clostridium scatologenes strain SL1 as Clostridium drakei sp. nov. Int J Syst Evol Microbiol 55, 2085-2091.

Mesbah, M., Premachandran, U. \& Whitman, W. B. (1998). Precise measurement of the $\mathrm{G}+\mathrm{C}$ content of deoxyribonucleic acid by high-performance liquid chromatography Int J Syst Bacteriol 39, 159-167.

Minnikin, D. E., O'Donnell, A. G., Goodfellow, M., Alderson, G., Athalye, M., Schaal, A. \& Parlett, J. H. (1984). An integrated procedure for the extraction of bacterial isoprenoid quinones and polar lipids. J Microbiol Methods 2, 233-241.

Mountfort, D. O. \& Rhodes, L. L. (1991). Anaerobic growth and fermentation characteristics of Paecilomyces lilacinus isolated from mullet gut. Appl Environ Microbiol 57, 1963-1968.

Pandey, K. K., Mayilraj, S. \& Chakrabarti, T. (2002). Pseudomonas indica sp. nov., a novel butane-utilizing species. Int $J$ Syst Evol Microbiol 52, 1559-1567.

Sato, N. S. \& Murata, N. (1988). Membrane lipids. In Methods in Enzymology, vol. 167, pp. 251-259. Edited by L. Packer \& A. N. Glazer. New York: Academic Press.

Schink, B. (1984). Clostridium magnum sp. nov., a non-autotrophic homoacetogenic bacterium. Arch Microbiol 137, 250-255.
Shin, C. Y., Lewis, T. A. \& Crawford, D. L. (1997). In In Situ and On-Site Bioremediation, vol. 2, pp. 23-29. Edited by B. C. Alleman \& A. Leeson. Columbus: Battelle Press.

Shivaji, S., Rao, N. S., Saisree, L., Reddy, G. S. N., Kumar, G. S. \& Bhargava, P. M. (1989). Isolates of Arthrobacter from the soils of Schirmacher Oasis, Antarctica. Polar Biol 10, 225-229.

Shivaji, S., Ray, M. K., Rao, N. S., Saisree, L., Jagannadham, M. V., Seshu Kumar, G., Reddy, G. S. N. \& Bhargava, P. M. (1992). Sphingobacterium antarcticus sp. nov., a psychrotrophic bacterium from the soils of Schirmacher Oasis, Antarctica. Int J Syst Bacteriol 42, 102-106.

Smibert, R. M. \& Krieg, N. R. (1994). Phenotypic characterization: In Methods for General and Molecular Bacteriology, pp. 607-654. Edited by P. Gerhardt. Washington, DC: American Society for Microbiology.

Spain, J. C., Hughes, J. B. \& Knackmuss, H.-J. (2000). Biodegradation of Nitroaromatic Compounds and Explosives. Boca Raton, FL: CRC Press LLC.

Spring, S., Merkhoffer, B., Weiss, N., Kroppenstedt, R. M., Hippe, H. \& Stackebrandt, E. (2003). Characterization of novel psychrophilic clostridia from an Antarctic microbial mat: description of Clostridium frigoris sp. nov., Clostridium lacusfryxellense sp. nov., Clostridium bowmanii sp. nov. and Clostridium psychrophilum sp. nov. and reclassification of Clostridium laramiense as Clostridium estertheticum subsp. laramiense subsp. nov. Int J Syst Evol Microbiol 53, 1019-1029.

Suresh, K., Reddy, G. S. N., Sengupta, S. \& Shivaji, S. (2004). Deinococcus indicus sp. nov., an arsenic-resistant bacterium from an aquifer in West Bengal, India. Int J Syst Evol Microbiol 54, 457-461.

Thompson, J. D., Gibson, T. J., Plewniak, F., Jeanmougin, F. \& Higgins, D. G. (1997). The CLUSTAL_X windows interface: flexible strategies for multiple sequence alignment aided by quality analysis tools. Nucleic Acids Res 25, 4876-4882.

Tourova, T. P. \& Antonov, A. S. (1987). Identification of microorganisms by rapid DNA-DNA hybridization. Methods Microbiol 19, 333-355.

Van de Peer, Y. \& De Wachter, R. (1997). Construction of evolutionary distance trees with TREECON for windows: accounting for variation in nucleotide substitution rate among sites. Comput Appl Biosci 13, 227-230.

Wayne, L. G., Brenner, D. J., Colwell, R. R., Grimont, P. A. D., Kandler, O., Krichevsky, M. I., Moore, L. H., Moore, W. E. C., Murray, R. G. E. \& other authors (1987). International Committee on Systematic Bacteriology. Report of the ad hoc committee on reconciliation of approaches to bacterial systematics. Int J Syst Bacteriol 37, 463-464.

Wilde, E., Collins, M. D. \& Hippe, H. (1997). Clostridium pascui sp. nov., a new glutamate-fermenting sporeformer from a pasture in Pakistan. Int J Syst Evol Microbiol 47, 164-170. 